\title{
Modelling Currency Crises in Nigeria: An Application of Logit Model $^{18}$
}

\author{
Babatunde S. Omotosho* \\ * Statistics Department, Central bank of Nigeria, Abuja, Nigeria \\ E-mail: bsomotosho@cbn.gov.ng
}

\begin{abstract}
Currency crises inflict significant social and economic costs on economies that have suffered its occurrence. Thus, statistical models have been developed over the years to construct reliable early warning systems as part of strategies for preventing or reducing the devastating effects of such crises. To the knowledge of this study, no recent work has been done in this regard with respect to Nigeria, especially following the 2008/09 global financial crisis. Using a logit model, this paper estimates the probabilities of currency crises in Nigeria as a logistic function of selected macroeconomic variables. Particularly, it provides answer to the question of whether real exchange rate misalignment propels currency crises. The empirical investigation used quarterly data for the period 2000:Q1 to 2012:Q4. Model results show that the likelihood of currency crisis in Nigeria increases when the real exchange rate is misaligned; the exchange rate is volatile; oil price declines; debt/GDP ratio increases; and the current account balance to GDP ratio declines. Real exchange rate misalignment has overarching influence on the tendency for currency crash during the estimation period. The paper therefore recommends regular assessments of the value of the Naira exchange rate vis-à-vis its equilibrium level with a view to implementing appropriate policy responses to arrest or avoid prolonged and substantial misalignments. Since all the variables entered the equation in their one period lag, the estimated model constitutes a reliable early warning system to policy makers on the likelihood of impending currency crisis in the country.
\end{abstract}

Keywords: Currency crises, exchange rate misalignment, exchange market pressure, logit model

\section{Introduction}

Following the collapse of the Bretton Woods system of fixed exchange rates in March 1973, the frequency and costs of currency crises have increased substantially. This unfortunate collapse led many developed countries to adopt the flexible exchange rate system while most developing countries responded by attempting to sustain their fixed exchange rate parities. Eventually, some of these developing countries abolished the fixed exchange rate system and embraced intermittent adjustments by implementing regimes such as the crawling pegs or the managed float. Their strategy is to avoid current account problems and currency crises via exchange rate policies. Consequently, exchange rate setting in those countries became the role and concern of monetary authorities rather than that of the market forces.

In Nigeria, exchange rate policies are implemented by the Central Bank of Nigeria (CBN) and consistently targeted at avoiding substantial misalignments as well as achieving a realistic Naira exchange rate that is capable of addressing the basic problems of the country's external sector. These ranged from a fixed exchange rate regime prior to 1986 to various forms of floating exchange rate system, following the liberalization of the foreign exchange market in 1986. Consequent upon the adoption of Social Adjustment Programme (SAP) in 1986, the Second-tier Foreign Exchange Market (SFEM) was introduced as a market-driven mechanism for foreign exchange allocation. Currently, foreign exchange transactions are guided by the Wholesale Dutch Auction System (WDAS), which was introduced on the 20th of February, 2006.

Historically, many currencies of the world have suffered crashes. These include the Bretton Woods system collapse of 1971-73, the British pound crisis of 1976, the European Exchange Rate Mechanism (EERM) mayhem of 1992-93, the Mexican peso crisis of 1994-95 and the Russian rubble crisis of 1998, amongst others. In fact, Hutchison and Noy (2002) noted that more than 51 currency crises episodes occurred in emergingmarket economies between 1976 and 2001. The pervasive socio-economic costs of such crises have also been widely documented in countries of diverse economic structures and monetary policy frameworks. For instance,

\footnotetext{
${ }^{18}$ This is based on a paper presented by the author at the $59^{\text {th }}$ ISI World Statistics Congress held in Hong Kong, China during August 25 - 30, 2013.
} 
Hutchison and Noy (2002) found a 5-8 per cent currency-crises-caused output reduction in emerging market economies while Bordo et al. (2001) estimated currency crisis cost amounting to 5-10 per cent of GDP. There is also evidence that currency crises can result to banking crises (i.e. the twin crises), especially when the banking sector holds substantial unhedged foreign liabilities during periods of sharp exchange rate depreciation (Glick and Hutchison, 2001). In this regards, the balance sheets of banks are negatively affected as the domestic currency value of their foreign liabilities become bloated. These historical perspective as well as the experiences of the 2008-09 financial crisis underscores the pervasiveness as well as the spread of currency crises via contagion.

Reinforced by the recent global financial crises is the need for early warning systems, as most of the past crises episodes were largely unpredicted and preemptive policies could not be taken to avoid their impending costs. To the knowledge of this study, no work has been done to model currency crises in Nigeria, especially after the 2008/09 global financial crisis which led the government to substantially intervene in the foreign exchange market (using foreign exchange reserves) in order avoid large changes in exchange rate. This paper seeks to bridge this gap by modeling the probabilities of currency crises in Nigeria as a function of selected macroeconomic variables, using a logistic function.

The rest of the paper is structured as follows. The next section reviews related empirical literature, with particular attention to variable selection and estimation methods. Section 3 focuses on the methodology for the study. The results are presented and discussed in section 4 while the final section concludes.

\section{Literature Review}

The first step in the measurement of currency crisis relates to crisis definition. A narrow definition includes successful attack on the currency that results in a substantial depreciation of the exchange rate. Based on this definition, studies such as Frankel and Rose (1996) defined currency crisis as a nominal depreciation of 25 per cent or greater, which is at least 10 per cent greater than the depreciation in the preceding year. Raising the threshold a little, Leaven and Fabian (2008) defined currency crisis as a nominal depreciation of the currency of at least 30 per cent that is also at least 10 per cent increase in the rate of depreciation compared to the year before.

In a broader sense, currency crisis is defined as a speculative attack on a country's currency that can result in a sharp depreciation or the need for the government to intervene in the market by selling foreign exchange reserves. This definition includes episodes of unsuccessful attacks as captured by large changes in the index of Exchange Market Pressure (EMP), defined as a weighted average of exchange rate changes and reserve losses. The intuition behind the EMP is that if there is an attack on the currency, either the exchange rate would depreciate or the central bank would sell foreign currency to support the exchange rate. Changes in the EMP above some threshold are deemed to represent crisis, defined as zeros and ones binary variable (one for crisis periods and zero for tranquil periods). For instance, Eichengreen, et. al (1995) used a one and a half standard deviation threshold, Glick and Hutchison (2005) and Glick et. al. (2006) used a 2 standard deviation threshold, while Kaminsky and Reinhart (1999) used a three standard deviation cutoff.

In terms of models of currency crisis, there are two popular methodologies in literature. These have been extensively used in the generation of early warning signals for currency crisis. These are the Signals approach, which is a non-parametric approach, and the limited dependent variable regression (Probit/Logit), which is a parametric approach to the anticipation of a currency crisis. The signal approach was introduced by Kaminsky et al. (1998), and further developed by Edison (2003). Kaminsky et al. (1998) monitored the evolution of several indicators with a view to assessing their relevance, individually in predicting currency crisis. Thus, if any of the macro-financial variables of a specific country tends to exceed a given threshold during the period preceding a crisis; it is interpreted as a warning signal indicating that a currency crisis in that specific country may take place soon.

On the other hand, the limited dependent variable regression models estimate the probability of a currency crisis as a function of selected factors. The two popular ones are probit and logit models. Within this framework, the currency crisis indicator is modeled as a binary response based on relevant input variables and the model predictions are interpreted as the probability of a crisis (Singh, 2010). The use of nonlinear methods such as probit/logit derives from the nonlinearity in the nature of relationship between economic fundamentals and currency crisis. Examples of empirical works that have used the probit model to predict currency crisis include Eichengreen et al. (1995, 1996) and Frankel and Rose (1996). Recently, Berg and Pattillo (1999), Komulainen 
and Lukkarila (2003) and Kumar et al. (2003) have also analyzed the predictability of emerging market currency crises using probit/logit models, whereas Bussière and Fratzscher (2002) used a more sophisticated multinomial logit model.

The variables often used in logit/probit models of currency crisis include money or domestic credit growth, the fiscal deficit, current account balance, real exchange rate misalignment, and output gap; as well as variables that gauge a country's vulnerability to attacks, such as measures of the adequacy of international reserves relative to possible short-run liabilities of foreign and domestic origin, foreign financing needs, and the overall soundness of the financial sector. Other variables include indicators of market expectations or investors' risk appetite, such as interest rate differentials, and exposure to contagion from crises in other countries. Trade and financial openness may also affect the likelihood of currency crisis (Frankel and Rose, 1996; Kaminsky et al., 1998; Kaminsky and Reinhart, 1998).

\section{Methodology}

In this study, currency crisis is defined using the concept of Exchange Market Pressure (EMP) developed by Girton and Roper (1977). They measured the EMP in country ' $i$ ' at time ' $t$ ' as:

$$
E M P_{i, t}=\left[\alpha \% \Delta \mathrm{e}_{\mathrm{i}, \mathrm{t}}-\beta \% \Delta n_{\mathrm{i}, \mathrm{t}}\right]
$$

where $e_{i, t}$ denotes the price of a U.S. Dollar in the country $i$ 's currency at the time ' $t$ '; $r_{i, t}$ denotes the foreign reserves (excluding gold) of country ' $i$ ' at the time ' $t$ ' and $\alpha$ and $\beta$ are the weights that equalize the variances of these two components. The first term, $\alpha \% \Delta e_{i, t}$ measures the percentage change of the price of a U.S. Dollar in country $i$ 's currency at the time ' $t$ '. The second term, $\beta \% \Delta r_{i, t}$ measures the percentage change in the level of the country $i$ 's foreign reserves. A positive value of the exchange market pressure index measures the depreciation pressure of the currency ' $i$ ', while a negative value of the index measures the appreciation pressure of the currency ' $i$ '. Thus, we define the currency crisis dummy variable as follows:

\section{Crisis $_{\mathrm{t}}=0$, otherwise}

$$
\text { Crisis }_{\mathrm{t}}=1 \text {, if } E M P_{\mathrm{t}}>E M P_{\mu}+2.0 E M P_{\mathrm{v}}
$$

where $E M P_{\mu}$ and $E M P_{\sigma}$ are the sample mean and the standard deviation of the computed exchange market pressure index for Nigeria. The classification of each time series observation as being in crisis or not depends on the whether or not the index exceeds an arbitrarily chosen threshold. In the literature, the values of a threshold have ranged between 1.5 to 3 standard deviations above the mean of the EMP. We decided to use a threshold of 2.0 for this study, similar to Glick and Hutchison $(2001,2005)$ and Glick, et. al. (2006).

Having constructed a currency crisis dummy as outlined above, we estimate a binomial logistic regression that models the probability of a crisis as a function of carefully selected explanatory variables based on the equation below:

$$
P_{t}=\frac{1}{1+e^{-\left(D_{1}+D_{2} x_{1}+\cdots+D_{t} x_{k}+k_{t}\right)}}
$$

where $P_{t}$ is the probability that there is currency crisis (i.e. Crisis $s_{t}=1$ ). The probability of currency crisis is related to a set of explanatory variables $x_{1}, x_{3}, \ldots, x_{k}$ and $\beta_{1}$ is the constant while $\beta_{2}, \ldots, \beta_{k}$ are the coefficients of the explanatory variables. The included input variables are: government expenditure as a ratio of Gross Domestic Product (government size), Gross Domestic Product gap (Output Gap), high inflation dummy (High Inflation), debt/GDP ratio, oil price growth, current account balance/GDP ratio (CAB/GDP Ratio), foreign private investment gap (FPIGap), exports growth, exchange rate volatility (RER volatility), real exchange rate (RER) and exchange rate misalignment (RER misalignment). The choice of the independent variables was based on theoretical models of currency crisis, which aim to capture domestic and external factors impacting on the probability of currency crisis. In addition, all used variables have been found to be related to currency crises in the empirical literature reviewed in section 2. Data on real exchange rate misalignment (RER Misalignment) was based on computed deviations of the actual real exchange rate from its long run equilibrium path. Also, data on exchange rate volatility was obtained from variance series obtained based on an estimated Generalized Autoregressive Conditional Heteroscedasticity $(\mathrm{GARCH})$ model of the naira-dollar real exchange rate. Time series data on the remaining variables used in the study are sourced from the Central Bank of Nigeria Annual 
Statistical Bulletin. The estimation period spans 2000:Q1 - 2012:Q4.

\section{Results}

The computed exchange market pressure based on equation (1) and the defined threshold based on equation (2) are presented in a time series perspective in Chart 1. It reflects pressures in the foreign exchange markets during Q4 2002 (a period shortly after the introduction of the retail dutch auction system of foreign exchange allocation in the country) and Q4 2008 - Q1 2009 (a period of the global financial crisis). Thus, these three periods are identified as crises periods in the estimation sample.

Chart 1: Exchange Market Pressure and the Crisis Threshold, 2000 - 2012

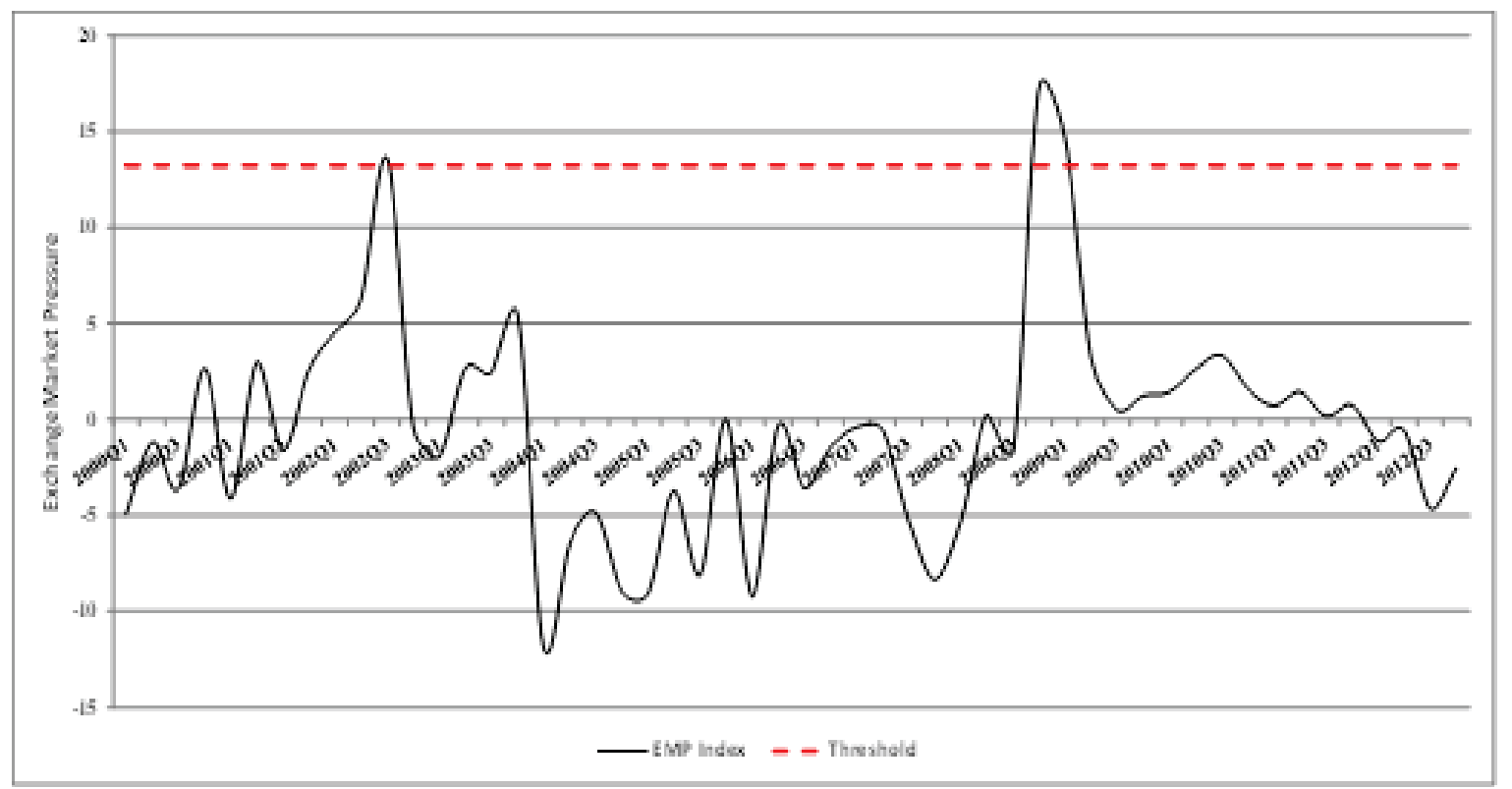

Table 1 presents the results of the logit model (equation 3) fitted to investigate the determinants of currency crisis in Nigeria. As can be seen from the table, most of the coefficients of the logit models are correctly signed and in line with currency crisis theories. The variables are also significant, implying that meaningful predictors were chosen to explain the probability of crisis in the country. The McFadden R-squared for the model is quite high at 0.83 while the deviance statistics is relatively low at 10.33 . All the variables in the model are significant at the 1 per cent level, except for $\mathrm{m} 2$ to reserves ratio and the high inflation dummy which are significant at the 5 per cent level and the second lag of growth in oil price which is significant at 10 per cent. Model results indicate that variables such as real exchange rate misalignment, the prevailing exchange rate regime (proxied by real exchange rate - RER movement), exchange rate volatility, exports growth, foreign private investment inflow gap (FPI gap), debt/GDP ratio, high inflation dummy (High Inflation) and government size increase the likelihood of currency crisis in the country.

However, increase in money supply/external reserves ratio (a measure of reserves adequacy), oil price growth and improved current account balance/GDP ratio (CAB/GDP Ratio) reduce the probability of currency crisis. 
Table 1: Regression Results of the Logit Model of Currency Crisis in Nigeria

Dependent Variable: Currency Crisis Dummy

Method: ML - Binary Logit (Quadratic hill climbing)

\begin{tabular}{|c|c|c|c|c|}
\hline Variable & Coefficient & Std. Error & z-Statistic & Prob. \\
\hline $\mathrm{C}$ & -51.7987 & 14.3172 & -3.6180 & 0.0003 \\
\hline RER Misalignment(-1) & 0.5761 & 0.1717 & 3.3547 & 0.0008 \\
\hline Govt. Size(-1) & 0.1352 & 0.0336 & 4.0287 & 0.0001 \\
\hline Output Gap(-1) & $-6.4 \mathrm{E}-05$ & $1.8 \mathrm{E}-05$ & -3.5281 & 0.0004 \\
\hline M2/Reserves Ratio(-1) & -0.0377 & 0.0182 & -2.0747 & 0.0380 \\
\hline High Inflation (-1) & 0.1169 & 0.0462 & 2.5327 & 0.0113 \\
\hline DEBT/GDP Ratio(-1) & 0.1200 & 0.0304 & 3.9429 & 0.0001 \\
\hline Oil Price Growth(-1) & -0.0017 & 0.0005 & -3.4395 & 0.0006 \\
\hline RER Volatility(-1) & 0.0019 & 0.0007 & 2.7137 & 0.0067 \\
\hline CAB/GDP Ratio(-1) & -0.5034 & 0.1587 & -3.1715 & 0.0015 \\
\hline $\operatorname{RER}(-1)$ & 0.0010 & 0.0003 & 2.6841 & 0.0073 \\
\hline FPIGap(-1) & 0.0002 & $6.2 \mathrm{E}-05$ & 3.3691 & 0.0008 \\
\hline Exports Growth(-1) & 0.1247 & 0.0314 & 3.9683 & 0.0001 \\
\hline Oil Price Growth(-2) & -0.0001 & $6.6 \mathrm{E}-05$ & -1.8174 & 0.0692 \\
\hline McFadden R-squared & 0.8314 & \multicolumn{2}{|c|}{ Mean dependent var. } & 0.1191 \\
\hline S.D. dependent var. & 0.3258 & \multicolumn{2}{|c|}{ S.E. of regression } & 0.1464 \\
\hline Akaike info criterion & 0.4564 & \multicolumn{2}{|c|}{ Sum squared resid. } & 1.4994 \\
\hline Schwarz criterion & 0.8616 & \multicolumn{2}{|c|}{ Log likelihood } & -5.1693 \\
\hline Hannan-Quinn criter. & 0.6193 & \multicolumn{2}{|l|}{ Deviance } & 10.3387 \\
\hline Restr. deviance & 61.3239 & \multicolumn{2}{|c|}{ Restr. log likelihood } & -30.6619 \\
\hline LR statistic & 50.9852 & \multicolumn{2}{|c|}{ Avg. log likelihood } & -0.0615 \\
\hline Prob(LR statistic) & 0.0000 & & & \\
\hline
\end{tabular}

In terms of magnitude, the coefficient of real exchange rate misalignment is large $(0.5761)$ underscoring its influence on the likelihood of a crash incidence in Nigeria. The fact that the included explanatory variables enter the model in their one period lag implies that they constitute early warning signals for currency crises in Nigeria. In view of the role of oil prices in external reserves accumulation and exchange rate determination in the country, a lag two of the oil price variable was also included in the model. The variable retained its sign as in its lag one but was significant at the 10 per cent level.

\section{Conclusion}

The purpose of this study was to examine the predictability of currency crisis in Nigeria during the last two decades based on the logit model. This paper is one of the first applications of the logit model to currency crisis modeling in Nigeria. Factors affecting currency crises in the country were evaluated with special focus on the macroeconomic fundamentals derived from the currency crises theories. The analysis showed that the included 
macroeconomic variables have statistically significant impact on the probability of currency crises in Nigeria. Particularly, we found that higher real exchange rate misalignment increases the probability of currency crisis in the country. This finding suggests the need for continuous and credible assessment of the naira exchange rate relative to its long run equilibrium value. A widening real exchange rate misalignment indicates the need for a policy shift. Thus, this paper recommends the continued use of market based exchange rate determination arrangement (such as the current Wholesale Dutch Auction System - wDAS) that is capable of preventing real exchange rate misalignment as a strategy for reducing the probability of currency crisis in the country.

\section{References}

Berg, A. \& Pattillo, C. (1999). Are currency crises predictable? A Test. IMF Staff Papers, 46 (2), 107 - 138

Bordo, M., Eichengreen, B., Klingebiel, D. \& Martinez-Peria, M.S. (2001). Is the crisis problem growing more severe? Economic Policy, 16 (32), 53-82

Bussiere, M. \& Fratzscher, M. (2002). Towards a new early warning system of financial crises. ECB Working Paper, No. 145

Edison, H. J. (2003). Do indicators of financial crises work? An evaluation of an early warning system. International Journal of Finance and Economics, 8(1), 11-53

Eichengreen, B., Rose, A. \& Wyplosz, C. (1995). Exchange market mayhem: The antecedents and aftermath of speculative attacks. Economic Policy, 21, 249-312

Eichengreen, B., Rose, A. \& Wyplosz, C. (1996). Contagious currency crises. NBER Working Paper No. 5681

Frankel, J. \& Rose, A. (1996). Currency crashes in emerging markets: An empirical treatment. Journal of International Economics 41, 351-366

Girton, L. \& Roper, D. (1977). A monetary model of exchange market pressure applied to the postwar Canadian experience. American Economic Review, 67, 537-548.

Glick, R. \& Hutchison, M. (2001). Banking and currency crises: How common are twins? in Glick, R., Moreno, R. \& Spiegel, M. M. eds.: Financial Crises in Emerging Market (Cambridge University Press, Cambridge; New York and Melbourne)

Glick, R. and Hutchison, M. (2005). Capital controls and exchange rate instability in developing economies. Journal of International Money and Finance, 24 (3), 387-412

Glick, R., Guo, X. \& Hutchison, M. (2006). Currency crises, capital account liberalization, and selection bias. Review of Economics and Statistics, 88(4), 698-714

Hutchison, M. \& Noy, I. ( 2002). Output costs of currency and balance of payments crises in emerging markets. Comparative Economic Studies, 44 (2), 27-44

Kaminsky, G. \& Reinhart, C. M. (1999). The twin crises: the causes of banking and balance-of payments problems. American Economic Review, 89(3), 473-500

Kaminsky, G., Lizondo, S. \& Reinhart, C. M. (1998). Leading indicators of currency crises. IMF Staff Papers, 45, 1-10

Komulainen T. \& Lukkarila J.(2003). What drives financial crises in emerging markets? Emerging Markets Review, 4, 248- 272

Kumar, M., Moorthy, U. \& Perraudin, W. (2003). Predicting emerging market currency crashes. Journal of Empirical Finance, 10, 427-454

Laeven, L. \& Fabian, V. (2008). Systemic banking crises: A new database,” IMF Working Paper No. 08/224

Singh, A. (2003) "Capital account liberalization, free long-term capital flows, financial crises and economic development. Eastern Economic Journal, 29 (2) 
This academic article was published by The International Institute for Science, Technology and Education (IISTE). The IISTE is a pioneer in the Open Access Publishing service based in the U.S. and Europe. The aim of the institute is Accelerating Global Knowledge Sharing.

More information about the publisher can be found in the IISTE's homepage: http://www.iiste.org

\section{CALL FOR JOURNAL PAPERS}

The IISTE is currently hosting more than 30 peer-reviewed academic journals and collaborating with academic institutions around the world. There's no deadline for submission. Prospective authors of IISTE journals can find the submission instruction on the following page: http://www.iiste.org/journals/ The IISTE editorial team promises to the review and publish all the qualified submissions in a fast manner. All the journals articles are available online to the readers all over the world without financial, legal, or technical barriers other than those inseparable from gaining access to the internet itself. Printed version of the journals is also available upon request of readers and authors.

\section{MORE RESOURCES}

Book publication information: http://www.iiste.org/book/

Recent conferences: http://www.iiste.org/conference/

\section{IISTE Knowledge Sharing Partners}

EBSCO, Index Copernicus, Ulrich's Periodicals Directory, JournalTOCS, PKP Open Archives Harvester, Bielefeld Academic Search Engine, Elektronische Zeitschriftenbibliothek EZB, Open J-Gate, OCLC WorldCat, Universe Digtial Library, NewJour, Google Scholar

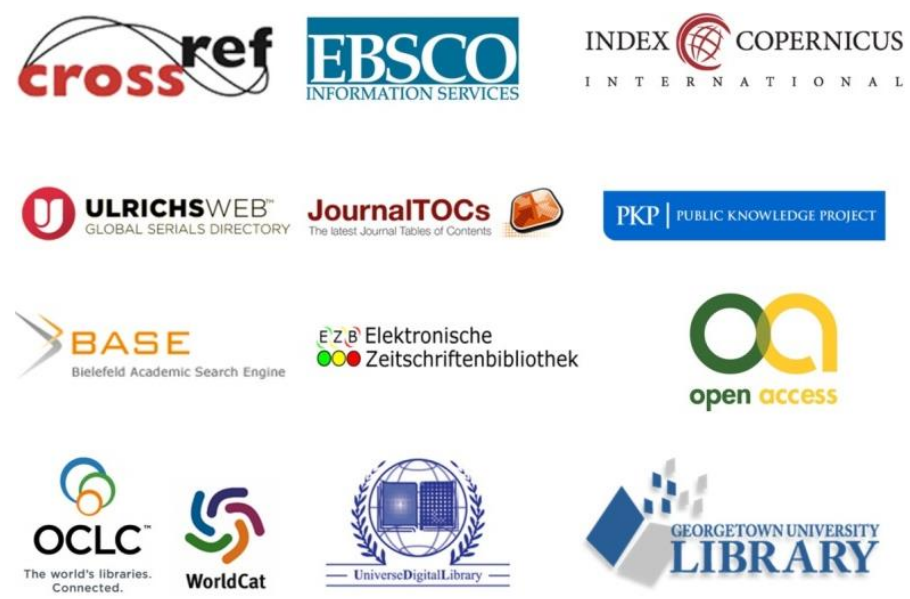

